\title{
Artisanal cheeses or artisanal Jesus - loving your postal code enough to reflect it in the life and theology of the church
}

\section{CJP (Nelus) Niemandt ${ }^{1}$}

\begin{abstract}
In this reflection on a creative and critical dialogue on the future of missiology as a theological discipline, the theological imperative of contextualisation was emphasised. The point of departure was that the contextual nature of theology, and thus missiology, must be at the forefront of the theological process. The relationship between Christianity and diverse cultures, and especially the relationship between faith and globalisation, were noted as some of the complex and challenging concerns of contemporary missiology that necessitate the development of alternative approaches to the witnessing and development of Christianity. It argued that the very fact of the incarnation, as well as the theological necessity of contextualisation and inculturation, provides the raison d'être for the future of missiology as a theological discipline. The research proposed attention to the following as part of missiology grounded in particular cultural contexts with the ultimate purpose of directing the practice of the Christian mission in its specific settings: discernment, a focus on ordinary life, emerging mission-shaped churches, and missional spirituality.
\end{abstract}

\section{Introduction}

On a visit to South Africa in May 2013 Prof. Leonard Sweet, the well-known theologian and author from the USA, made the point that people are rediscovering their neighbourhoods. Food is turning towards "locavore" (local foods) and the world towards a celebration of particularity (Sweet 2010:192). Paradoxically, the world is also going "glocal" - signifying the dynamic interrelatedness of the global and local (see also Van Engen 2006:157). Sweet said that the church must love its local postal code enough to reflect it in the life and theology of the church. To illustrate his remark, he referred to the resurgence of interest in artisanal cheeses. In reply, a theological student tweeted on Twitter "Did Leonard Sweet make a point for artisanal cheeses or artisanal Jesus?"

I want to take up the point of an "artisanal Jesus". In more formal theological terminology, it raises the issue of the incarnation of Jesus Christ, as well as the importance of contextualisation and inculturation. In terms of a creative and critical dialogue on the future of missiology as a theological discipline, I argue that the very fact of the incarnation, as well as the theological

1 Prof Nelus Niemandt is the Head of the Department of Science of Religion and Missiology, Faculty of Theology, Univ. of Pretoria. His email address is: nelus.niemandt@up.ac.za. 
necessity of contextualisation and inculturation, provides the raison d'etre for the future of missiology as a theological discipline. Faith is contextual (Bosch 1991:421). Pears (2009:1) states that Christian theology is and has always been contextual. Bevans (2002:3) argues that doing theology contextually is not an option. As long as theology engages with the gospel and context, and as long as the interrelatedness of Gospel and context continue, theology will not be able to escape the issue of contextualisation, and consequently an acknowledgement of the contribution of missiology. Missiology provides, par excellence, the framework, insight, knowledge and reflection on contextualisation. Bosch (1991: 497) argued that missiology's concern will always be a "contextual eludication of the relationship between God, God's world, and God's church". It navigates the dynamic tension between text and context. Missiology is particularly well suited to assist the church and theology in this process; in the art of crossing borders. The theological imperative of contextualisation means that the life of the church, theology and thus theological training cannot do without missiology. This is relevant in terms of both aspects of the (paradoxical) glocal or "bifocal" (Shenk 2006:11) context - the church of the 21st century is indeed glocal in its essence and in its theologising (Van Engen 2006:163,172). In terms of the ever increasing impetus of globalisation, missiology will practise a "globalising theology" that takes into account the fact that we live with an intensified awareness of the global. It will utilise the insights of missiology, and the understanding of mission as contextualisation, to prepare a truly diverse menu to feast on the diverse perspectives of Christian communities throughout the world, with a view to a greater holiness in living and faithfulness in fulfilling God's mission in all the world (Netland 2006:30). In terms of the ever intensifying focus on the local, missiology will, again, utilise its insights into contextualisation to prepare a truly artisanal feast that will invite locals to share in the "bread of life".

If Christian theology and Christian churches understand the need to show respect to the surrounding context; if it is important to communicate God to the context; if the imperative to bring context into the kingdom is understood; then missiology, with its particular emphasis on incarnation, contextualisation and inculturation and will come into play. As Roxburgh (2011:26) puts it:

When we are truly seeking to know what it means to be God's people, we will want to know what God is up to in our neighbourhoods and communities and what it means for the gospel to be lived out and proclaimed in this time and place. The matter of getting someone to church is utterly secondary to these insights. Now we are in a place where ecclesiology isn't the issue. Missiology is.

Missiology is the issue because of the impact of change on society, the church and theology. As Diane Butler Bass (2012:31) puts it: "We live in a time of momentous historical change that is both exhilarating and frightening. Christianity itself is becoming something different from what it was." As long 
as contexts change and as long as the ever-changing rhythms of different times ${ }^{2}$ beat over the world, missiology, with its particular sensitivity towards contextualisation, and with its ability to facilitate the crossing of borders, will be needed to guide the church and theology in crossing barriers and imagining God's future.

The aim of this research is to take up the challenge posed by Pears $(2009: 1,9)$ to put the contextual nature of theology at the forefront of the theological process, and thus to reiterate the indispensible role of contextualisation, to affirm the connection between missiology and contextualisation, to ground the enterprise of contextualisation in the incarnation, and to emphasise the importance of contextualisation and inculturation in changing contexts. The research will map ideas for the way forward and propose attention to discernment, greater focus on context, attention to ordinary life, emerging missional churches and missional spirituality, as important themes for missiology. Pears (2009:2) states that contextual theology is still in its relative infacy, and this research endeavours to articulate some of the contextual factors that motivate and shape missiology.

To return to the metaphor of artisanal food - as long as people eat food, and as long as menus change, missiology will be on the menu of theology. Food, hence also eating, represents one of the primal aspects of life itself. The sharing of food is the sharing of life. I agree with the World Council of Churches (2013:75) when it says: "We affirm that dialogue and cooperation for life are integral to mission and evangelism", and therefore also affirm the close connection between food and theology. Wirzba (2011:loc 102) says "Created life is God's love made tastable and given for the good of another. The mundane act of eating is thus a daily invitation to move responsibly and gratefully within this given life. It is a summons to commune with the divine Life that is presupposed and made manifest in every bite." Food and eating are an expression of life and thus culture. Modern culture's fascination with food, as can be seen in the abundance of TV shows about food and cooking (Masterchef, Kokkedoor, Nataniël tafel), reminds us of the close connection between food and faith, theology and eating, and mission as "eating and drinking whatever they give you" (Luke 10:7).

Eating is an invitation to enter into communion and be reconciled with each other, to give and receive, a tangible practice of peace and unity, and it reminds us of the incarnation.

\section{Incarnation}

Making a point for the artisanal Jesus means that one must be serious about the missio dei, and thus the incarnation of Christ (Niemandt 2011:73). Doing theology means becoming engaged in the missio dei - the missio dei is focused on this world, and it makes sense to understand what is happening in the world

2 Heitink's (2011) term “Golfslag van de tijd" can hardly be translated. 
because Christians are to be its light; Christians are to be salt in this world (Hendriks 2013:825-826). The incarnation informs this engagement and the way we interact with the complex, ever-changing, glocal world around us.

The concept of the incarnation reminds us of the self-giving of the Triune God. Volf (2006:4) says that the nature of God fundamentally determines the character of the Christian life. If self-giving typifies the life of the Trinity, it is not surprising that self-giving is at the heart of the divine missions to the world. Trinity is the ground, means and goal of mission (So 2013:137). God's decision to be for humanity is reflected in the creation of the natural and human orders. God retains his utter separateness. At the same time, creation is an act of divine self-giving. "God puts some of himself into creation, just as we might say of musicians, 'They put themselves into that piece.' They left traces of themselves in the music they played. Likewise, God leaves traces of himself in creation, not least in humanity" (Moynagh, 2012: loc 3641). As Wirzba (2011:163) says: "By being the incarnation of God the Father, Jesus is showing humanity how to receive and love everything in this world with a divine point of view." Bergmann (2003:15) and Pears (2009:118) argue that the incarnation of God in Christ is at the centre of the Christian faith. For Bergmann (2003:17) this means that creation is the very centre of Christian theology, and contextual theology means that different communities have the task to reflect theologically on the meaning of creation in their particulars contexts.

The missionary message of the Christian church incarnated itself in the life and world of those who had embraced it (Bosch 1991:421). Moynagh and Harold (2012:loc 1002) describe the important role of Paul in formulating missional strategies and says Paul adopted an "incarnational" strategy based on being attentive to context, loving and serving, building community, allowing individuals to come to faith at different paces, in the midst of life. His churches were culture specific with indigenous forms of leadership. I appreciate Hirsch's (2006:37) description of "proximity space" - the missional space where culture could be engaged on its own turf. It is the space where the church is taken to the people.

The incarnation is thus a key paradigm for contextualising the church. Jesus was thoroughly immersed in his Jewish culture, speaking Aramaic with a Galilean accent and taking part in his society's celebrations and traditions. His parables drew upon the Jewish thought categories and rhetorical traditions of his day (Flemming 2005:21). The Bible is, by its very nature, contextual. It is an incarnational analogy in its union of the human and divine. In taking different shapes according to the context, the church is following a well known pattern in adapting itself to the setting.

The life of the church as life in the Trinity, and the fundamental importance of the incarnation as a movement towards where people are, necessitates precisely what missiology brings to the table. We need to regain 
a missional-incarnational ethos with a heart for healing and restoration of a world caught up in brokenness and loss of life (Kok and Niemandt 2009:3). To be incarnational, we have to cross boundaries, break down social constructionist symbolic fences and barriers, build bridges that create the possibility of open communication and interaction. Kok and Niemandt (2009:6) argue that the church needs to be incarnational instead of attractional: Jesus's incarnational ethos results in the bringing of the presence of God into marginalised places or spaces where such presence is usually believed not to be found. Crossing boundaries means to focus on being church in the world, mostly in marginalised, liminal spaces. Such a church is missional by intent where daily life is seen as an expression of the sent-ness by God into this world (Frost 2006:151). To adapt Sweet missiology is awakening each other to the God who is already there - "The doctrine of the incarnation requires a high doctrine of the everyday, the ordinary" (Sweet 2010:103).

\section{Contextualisation and Inculturation}

Mission is "eating and drinking whatever they give you" (Luke 10:7). Theology must serve context (West 2013:920), and context informs theology.

David Bosch famously described elements of an emerging ecumenical missionary paradigm and referred to "Mission as contextualization" (Bosch 1991:420-432) and "Mission as inculturation" (inculturation being a second important model of contextualisation) (Bosch 1991:447-456). Bevans and Schroeder argue that Christian mission needs to be radically contextual (2004:31) and describe inculturation ${ }^{3}$ (including both the ideas of contextualisation and inculturation) as a component of mission (see also Kritzinger 2011:45). "Inculturation is acknowledged today as an integral part of communicating the gospel, if the gospel, indeed, is truly to be communicated" (Bevans and Schroeder 2011:69).

Contextualising the church is the attempt to be church in ways that are both faithful to Jesus and appropriate to the people the church serves. It assumes that the shape of church can change according to the situation. Churches will look different because they are engaging with different people (Moynagh 2012:loc 4278). If the church is to serve its context, it must connect to it. This happens through contextualisation. Andrew Walls referred to this as the indigenising principle. "The impossibility of separating an individual from his social relationships and thus from his society leads to one unvarying feature in Christian history: the desire to 'indigenize,' to live as a Christian and yet as a member of one's own society" (Walls 1996:7). In terms of Walls's argument, the New Testament

3 See Ukpong (2013:531-533) for a more comprehensive description of the term 'inculturation'. 
witness is predisposed towards any particular cultural captivity of the gospel, precisely because of the possibility of salvation in Christ for those outside the first Jewish communities. For him, indigenisation is not only a possibility, but an important requirement for followers across different cultures to be authentic disciples of Jesus. One can say that, in terms of Walls's understanding, Christianity shares common ground across cultures, but it also diversifies and accommodates itself to local patterns of thought and practice. The essential catholicity of the church prevents cultural and other differences from developing into division, and contextualisation creates the safe space to affirm the particulars of any culture and group within the broader Christian story and community. Elsewhere, Walls states that the theological agenda is culturally induced; culture necessarily sets new tasks for theology (Walls 2009:49). One cannot engage with the gospel independently of culture (Shenk 2006:9).

Theology mediates the meaning and role of religion to a culture (Bevans 2002:11). The point made by Bosch in his description of contextualisation is still as relevant as ever - mission as contextualisation is an affirmation that God has turned toward the world. Mission as contextualisation involves the construction of a variety of "local theologies" (Bosch 1991:427).

Inculturation is closely related to contextualisation ${ }^{4}$. According to Bosch (1991:447), "inculturation is one of the patterns in which the pluriform character of contemporary Christianity manifests itself." The changing nature of the context in which Christian faith and Christian theology finds itself means that Christian faith and theology ought to rethink and reformulate its relationship with each human culture: "and this must be done in a vital way, in depth and right to the cultures' roots" (Bosch 1991:452; see also Niemandt 2011:73). Inculturation is the creative and bold response to the contexts in which the church finds itself (Bevans and Schroeder 2004:1). Tennent's definition of inculturation is very helpful: "formulating, presenting and practising the Christian faith in such a way that is relevant to the cultural context of the target group in terms of conceptualization, expression and application; yet maintaining theological coherence, biblical integrity and theoretical consistency" (Tennent 2010:loc 3898-3900). Inculturation is a two-way process of interaction between Christian faith and a culture that effects transformation of the culture and a re-interpretation of faith (Ukpong 2013:531).

4 Bevans and Schroeder (2004:385) use the two terms as synonyms - “...mission has always engaged in what is today called the process of inculturation or contextualization" (See also Kim 2009:185) In this research, the focus is not on a description of the differences between contextualisation and inculturation. Schreiter (2007:1) is followed in his argument that terms such as contextualisation, inculturation, localisation and indigenisation refers to the same basic issue - the need for and responsibility of Christians to make their response to the gospel as concrete and lively as possible. 
The renewed appreciation of inculturation can be seen in the World Council of Churches' (2013) report on mission and evangelism, Together towards life: mission and evangelism in changing landscapes. Respect for people and their cultural and symbolic life-worlds is necessary for the gospel to have a better reception. The WCC (2013:72) states the indispensable nature of inculturation: "the embodiment which the Word assumes in a particular community or culture." Its source and inspiration are in the mystery of the incarnation. The context of the recipients and agents of missional activity influences their scope and character; therefore mission must be understood as contextual, thus referring to the social location of all those who are engaged in mission work (World Council of Churches 2013:59). Wherever the gospel is expressed - east, west, north or south - it is the story of God's dealings with a particular people and creation, in a particular context and coming to us in the historical person of Jesus Christ (World Council of Churches 2013:72):

It is imperative to address the contextual realities which have shaped and which continue to shape and/or impede people's experiences of the fullness of life. Missiological reflections have to recognize the differences in perspectives and the consequent value orientations that shape missional perspectives. (World Council of Churches 2013:59)

Kritzinger's (2011:49-52) interpretation of the praxis approach is helpful with its emphasis on "contextual understanding", as well as the description of transformative encounters:

Mission as praxis is about concrete transformation; it is specifically about transformative encounters: among people, and between the living God and his people, leading to people being called, sent, healed, and empowered. It is about the reign of God that has entered into this broken world. (Kritzinger 2011:52)

This understanding of missiology calls the metaphor of a midwife to mind - this is a role that involves both creating conditions which give birth to new realities as well as eliminating impediments which impose constrains on communities preventing them from experiencing life in fullness (see also Manchala, Rajkumar and Prabhakar 2013:41).

Missiology, with its particular emphasis on contextualisation, is ideally suited to accompany the church and to enrich theology in its interrelatedness with an ever-changing, glocal world. This means that the focus of a local church and its leaders needs to be on two things. First, the focus must be on the ordinary lives of the people of a local congregation through which the Spirit is shaping a new future. Second, the focus must be on the local contexts as the venues for discerning and engaging that future (Roxburgh 2011:167). 


\section{Inculturation and transformative encounters against the backdrop of changing contexts}

This reflection is not an effort to redefine mission by, for example, reducing Bosch's elements of an emerging paradigm, or Bevans and Schroeder's components of mission to a singular focus on incarnation and contextualisation. It rather tries to show that these three aspects of mission enable missiology, as a discipline in theology, to facilitate transformative encounters in the light of a rapidly changing context. Missiology is, in a certain sense, the art of crossing borders. The church finds itself in challenging times, (Niemandt describes it as a perfect storm 2007:10-11) times that create a shifting world and ever changing borders, and the enterprise of theology can benefit from the intrinsic capabilities of missiology to reflect on transformative encounters and the praxis of crossing borders.

We live in a shifting world. The respected sociologist Manuel Castells (2004) makes a strong point in describing the changes in our times, energised by the combined impact of globalisation, informalisation and technology (see also Hendriks 2013:820). The fact of the matter is that contexts are constantly changing. The WCC (2013:72) says: "The contemporary context of evangelism is one of many cultures which overlap, interact and sometimes clash with each other. The gospel takes root in different contexts through engagement with specific cultural, political and religious realities." Castells (2004:3-4) says the networking form of organisation and its varied forms of communication, its flexibility and power is transforming society, culture and the way we experience time and space. This shift is magnified by globalisation. Globalisation is the multidimensional force, driven by people, which leads to a world of interconnectivity, communication, trade and inter-dependence, where the whole planet becomes a locality (Volf 2009). Human mobility and migration are closely associated with and reciprocally influenced by globalisation. Add the relentless connectivity (Castells et al. 2007:loc 4894) and immense pace of globalisation, facilitated by the proliferation of mobile communication and the emergence of social media to this mixture, and an emerging new 'glocal' culture is evident. People are not only migrating to new localities and territories, but simultaneously into a new culture. Faith and globalisation constitutes two of the most powerful forces of our time, (Volf 2009). We need to master the art of crossing these new borders so that the gospel can take root in these new contexts. Culture flows like a river and the church functions as a bridge connecting humans striving to make sense of life and Scripture as well as tradition transmitted over the centuries. Some of the missional challenges will be to incarnate the gospel in this emerging culture. We need to find a way forward, and missiology can assist in providing direction and a vision of what is yet to come. 


\section{The way forward}

The reflection on missiology as a theological discipline is rooted in the past, practised in the present, but we must keep our vision fixed on what is yet to come (McCoy 2013:527). Missiology is the critical reflection and research on the theory and practise of Christian mission. Missiology seeks to translate the message of the Gospel not only into the language but also into the culture, stories, and thought forms of its recipients. I find the description of Kravtsev (2012:8) appropriate:

Missiology is an academic discipline aimed at understanding and explaining the specifics of the church's missionary calling in light of the missio dei. Being biblically based, it is historically informed, theologically balanced, and grounded in particular cultural contexts with the ultimate purpose of directing the practice of the Christian mission in its specific settings.

We have a new world. We have a new church. We need a new approach to theology, ecclesiology and missiology. The future of missiology as a theological discipline is at stake. Perhaps the following contours can enhance the ability of missiology to reflect on the incarnation of the gospel in the emerging global/glocal culture.

\section{Discernment}

Osmer (2008), in his authoritative book on Practical Theology (Practical Theology. An introduction), discusses "Prophetic discernment" as the normative task of Practical Theology. It involves both divine disclosure and the human shaping of God's word (Osmer 2008:134), and entails listening to this Word and interpreting it in ways that address particular social conditions, events and decisions before congregations (Osmer 2008:135). "Discernment is the activity of seeking God's guidance amid the circumstances, events, and decisions of life" (Osmer 2008:137) He also discusses the importance of a spirituality of prophetic discernment. To discern means to sift through and sort out, to weigh the evidence before reaching a decision. A guideline for such discernment is suggested in the WCC (2013:73) policy document on mission and evangelism: "We affirm that the purpose of God's mission is fullness of life (John 10:10) and this is the criterion for discernment in mission."

Discerning "fullness of life" underlines the relevance of discernment in the discussion of the future of missiology as a theological discipline. The concept is deeply tied to the idea of participating in God's mission, as mission is a process to discern where the Triune God is working (missio $d e i$ ), and joining in and participating in the mission of God (Niemandt 2013:70). 
Mission involves joining in with the Spirit or, in the words of Archbishop Rowan Williams, "finding out where the Holy Spirit is at work and joining in" (Kim 2009:1). Missiology builds on the missio dei, the active presence of the Triune God in his creation and the life-changing invitation to participate in this mission of God. A missional church is a community of followers called by the Spirit on a journey of discernment. The church is the pilgrim people of God. Missiology acknowledges the turn towards discernment by God's pilgrim people. As Jurgens Hendriks (2004:30) puts it: "The solution to faith communities' questions about how to participate in God's missional praxis is a critical, constructive dialogue or correlation between their interpretations of the realities of the global and local context and the faith resources at their disposal." Discernment is the first and most decisive step on this missional journey. It is the most prominent contour of missional leadership and a core practice of Christian leadership. Discernment is the art of reading the times and signs. It is the biggest single challenge facing spiritual leaders in this world of changing contexts and borders (see also Sweet, 2004:59). The new policy document of the World Council of Churches on mission and evangelism asks the question: How and where do we discern God's life-giving work that enables us to participate in God's mission today? (World Council of Churches 2013:51). It says:

The churches are called to discern the work of the life-giving Spirit sent into the world and to join with the Holy Spirit in bringing about God's reign of justice (Acts 1:6-8). When we have discerned the Holy Spirit's presence, we are called to respond, recognizing that God's Spirit is often subversive, leading us beyond boundaries and surprising us. (World Council of Churches 2013:56)

It highlights the fact that the gospel takes root in different contexts through engagement with specific cultural, political and religious realities, and calls for engagement and dialogue with the wider context in order to discern how Christ is already present and where God's Spirit is already at work. The skill of discerning is the door to transformation, to renewal of our personal lives, the beginning of the renewal of faith communities and the world. It is about awakening each other to the God who is already there, nudging people to pay attention to the mission of God in their lives and to the necessity of responding to that initiative in ways that "give birth to new realities" (Sweet 2010:29).

The speed of change, as well as the nearly overwhelming intensity of the exhilarating and frightening historical changes that are characterising the contemporary Christian story, the adaptive challenge posed by leadership in a changing world, all of these and much more challenge the church to prophetic discernment by entering the trialogue. 


\section{Entering the trialogue}

The trialogue is the discerning interaction between church, culture and biblical narrative. Roxburg (2011:51) says that the Gospel in our Culture Network (GOCN) developed this concept and stressed the importance of a trialogue between church, culture and the Gospel (although Conn had used the concept of "trialogue" in his 1984 book Eternal word and changing worlds: Theology, anthropology, and mission in trialogue). Roxburgh proposed the idea of a trialogue as an escape from the exclusive focus on the church of pre- and post-Eurocentric Reformation (Roxburgh 2011:51), because the "ecclesial element, the conversation about missional church, has subsumed the other two with its agenda, so we see gospel and culture through the lens of church" (Roxburgh 2011:54). This is very similar to Ott's (322-323) description of theological triangulation. In his description revelation (or the Gospel), culture and theology (or the church) are in a triangular relationship, with revelation (text) and culture (context) in a creative tension. He conceptualised the idea of a parabolic headlight to establish the relationship between text and context in a way that retains scriptural authority and priority while allowing for local diversity. In this conceptualisation revelation is determinative and culture reflective.

The trialogue entails to discern together - to seek, discover, understand and share in what the Holy Spirit is up to in the close-to-the-ground particulars of the church's engagement in, with, against and for the world. Furthermore, this missional turn to discernment will be decidedly ecclesial, churchly, and in this way will not be dominated by the clergy, colonised by individualists or determined by win-or-lose majority votes To discern what God is up to is to be aware that the Holy Spirit may work in strange and unexpected places. God's Spirit is at work in actual cultures, organisations and persons (Niemandt 2012:8-9) This reminds me of Kritzinger's (2011:152) "encounterology", and the description by Kritzinger and Saayman (2011:152) of mission as transformative encounters across frontiers.

\section{Ordinary life, ordinary eating}

This facet of discernment, and the focus of the trialogue on culture, brings the issue of a doctrine of the everyday and the ordinary to the forefront. Transformative encounters happen in ordinary life. Missiology seeks to assist missional, contextual churches to be church in settings of ordinary life. It addresses the needs of people in their ordinary lives (Moynagh and Harrold: loc 1559). Roxburgh (2011:132) says it is among the ordinary people of God, the nameless people who never stand on stages or get their photo in the newspaper, where God's boundary-breaking future will emerge. The local and ordinary are keys to how churches, theology and missiology will reform to join again with the mission of God in the world. 
One of the most ordinary, everyday events, and one yet infused with deep theological significance, is ordinary eating and food. In a certain sense, one of the most important and decisive missional moments in Acts (10) was when Peter refused to eat from the feast of "all kinds of four-footed animals, as well as reptiles and birds" set before him. For Jesus, eating with sinners and outsiders was not symbolic; it was a clear practice of the kind of peace, equality and unity he proclaimed (Stone 2013:loc 666). Wirzba (2012:11) says Trinitarian-inspired eating means that we eat to share and nurture life. To share food is fundamentally to share life. To turn around the thesis of the WCC, describing the mission of affirming and preserving life (World Council of Churches 2013:74): we will only be able to affirm, share and preserve life, if we are able to share food and sanctify ordinary eating. Sweet uses the term "nudge" in his book on mission and evangelism, and says "food nudges" are some of the most powerful revelations of God's goodness and glory (Sweet 2010:172). Perhaps missiologists must pay much more attention to food and eating in their reflection on mission and the future of Missiology as a theological discipline.

Roxburgh also recognises the importance of a missiological reflection on the importance of eating, and in his discussion of the sending of the seventy-two (Luke 10:1-20), he states that entering houses of strangers, being powerless and dependent on the hospitality of others, and eating with others, lie at the heart of being missional (Roxburgh 2011:139). In every culture, sharing meals is a powerful sign of acceptance and care (Stone 2013:loc 180). It is about entering deeply into the life of the other on his or her terms, not your own. The rule of eating what is set before us is about our readiness to enter into the world of the other on his or her terms rather than our own (Roxburgh 2011:172). "The table is a symbol of where God is taking all of creation. More than a symbol, it is a sacrament that can engage us directly in the life of God" (Roxburgh 2011:144)

\section{Mission-shaped church}

In Nuwe drome vir nuwe werklikhede, Niemandt (2007) made a case for new forms of emerging missional churches. Kim (2009) in her chapter "Discerning the Spirit: Among peoples and cultures" also made a point that mission is not only about changing the church, but also about changing society. She identified "fresh expressions of church" as a situation where cultural forms determine the form of church (Kim 2009:63). Wild-Wood and Rajkumar (2013:251-252), in their exploration of the foundations for mission in the light of Edinburgh 2010 and Cape Town 2010, in the Regnum Edinburg Centenary Series (Foundations of mission), identifies emerging or fresh expressions of church, which are mission shaped, as a new form of mission. They say: 
From understanding mission in relation to the doing of the church, mission can now be understood in relation to the being and becoming of the church, for an incarnational mission. Of course mission as being related to the being and becoming of the people of God is a salient biblical feature, but the institutionalisation of this biblical precedence in recent ecclesial practice opens space in thinking of mission in terms of ecclesial form. Such an ecclesia shaped by and responding to context transcends popular configuration of mission in the language of the imperative - what we ought to do - and frees us to re-configure mission in the language of the indicative - of who we are and are to become."

(Wild-Wood and Rajkumar 2013:251)

The WCC mentions "emerging churches" in the latest Faith and Order report The Church: Towards a Common Vision and says emerging churches propose a new way of being the Church, challenging other churches to find ways of responding to today's needs and interests in ways which are faithful to what has been received from the beginning (World Council of Churches 2013:10).

Ecclesiology has become more missiological as it realises that it is God's mission -sending the Son and the Spirit - that calls the church into being. Missiology has become more ecclesiological by recognising that the church is how God's mission takes shape (Bevans 2002:45-9). The church does what it is and then organises what it does. A missional ecclesiology (what the church is) might assist the church in these times of intense changing of contexts and of liminality, so that what the church does reflects the incarnational, contextual incultured nature of a missional church.

\section{Missional spirituality}

A missional church is characterised by a missional spirituality. This is a transformative spirituality (World Council of Churches 2013:57) that gives meaning to our lives and stimulates, motivates and gives dynamism to life's journey. Missional spirituality is a spiritual awareness of God's presence and of life in the Trinity. It is imperative in the journey of transformation and being transformed. It is a spirituality of the everyday, as all spirituality is missional spirituality. Kim (2009:256) describes it as a spirituality that is orientated to the world. It connects the human spirit in mission with the Spirit of God sent onto the world. Missional spirituality is a spirituality for the road, one that you can carry with you into the rough-and-tumble of everyday life (Helland and Hjalmarson 2011:loc 53). NT Wright (2008:270) says that there is ultimately no justification for a private piety that doesn't work out in actual mission. Missional spirituality shifts the focus from the missionary task to the ethos and ethics of mission, to the way in which mission is carried out, to the praxis and process of mission (Kim 2009:256). 


\section{Conclusion}

I am convinced that any dialogue on the future of missiology as a theological discipline will acknowledge the important and indispensable role of missiology in assisting the church and theology to artfully cross borders and navigate the storms of change. Yes, mission is complex in a complex world. To only way for theology to "eat and drink whatever is provided" is to embrace a menu - and theology - that acknowledges incarnation, contextualisation and inculturation. This can be done when missiology enters the trialogue - a discerning interaction between church, context and biblical narrative. The future of missiology necessitates alternative approaches to the witnessing and development of Christianity, such as a focus on discernment, ordinary life, emerging mission-shaped churches, and missional spirituality.

One is reminded of Ross's (2008:xv) words:

Mission is complex; it is multi-faceted; different concerns emerge from different places as we try to follow and present Jesus in our place. However, these different issues will touch us all as we allow new insights from different contexts to enter our perspectives and enlarge our borders.

\section{Bibliography}

Bass, D.B., 2012, Christianity after religion. The end of church and the birth of a new spiritual awakening. New York: HarperOne.

Bergmann, S., 2003, God in context: a survey of contextual theology. Aldershot:Ashgate.

Bevans, S.B., 2002, Models of contextual theology. Maryknoll, NY: Orbis.

Bevans, S.B. \& Schroeder, R.P., 2004, Constants in Context. A theology for mission today. Maryknoll, NY: Orbis.

Bevans, S.B. \& Schroeder, R.P., 2011, (2011). Prophetic Dialogue: Reflections on Christian Mission Today. Maryknoll, NY: Orbis.

Bosch, D.J., 1991, Transforming Mission. Maryknoll, NY: Orbis.

Castells, M., 2004, The power of identity: The information age: economy, society and culture, volume II. Oxford: Blackwell.

Castells, M., Fernandez-Ardevol, M., Qiu, J.L. and Sey, A. 2007, Mobile Communication and Society. A global perspective. Cambridge, Massachusetts: MIT Press [Kindle] 
Conn, H.M., 1984, Eternal word and changing worlds: Theology, anthropology, and mission in trialogue. Grand Rapids: Zondervan.

Flemming, D., 2005, Contextualization in the New Testament. Patterns for theology and mission. Leicester: Apollos.

Frost, M., 2006, Exiles: Living Missionally in a Post-Christian Culture. Peabody, Mass: Hendrickson.

Heitink, G., 2011, Golfslag van de tijd. Europa's niet te stillen verlangen naar God. Kampen: Kok.

Helland, R. and Hjalmarson, L., 2011, Missional spirituality. Embodying God's love from the inside out. Downers Grove: InterVarsity [Kindle].

Hendriks, H.J., 2004, Studying congregations in Africa. Lux VerbiBM, Wellington.

Hendriks, H.J., 2013, 'Contextualising theological education in Africa by doing theology in a missional hermeneutic' in Phiri, IA and Werner, D (eds.), 2013, Handbook of theological education in Africa. Dorpspruit: Cluster: 818-831.

Hirsch, A., 2006, The forgotten ways. Reactivating the missional church. Grand Rapids: Brazos.

Kim, K., 2009, Joining in with the Spirit. Connecting world Church and local mission. London: Epworth.

Kok, J. and Niemandt, C.J.P., 2009, '(Re)discovering a missional-incarnational ethos', HTS Teologiese Studies/Theological Studies, 65(1), Art. \#274, 7 pages. DOI:10.4102/hts.v65i1.274.

Kravtsev, A., 2012, What is missiology? See https://www.academia.edu/4809782/WHAT_IS_MISSIOLOGY. Accessed on 9 Dec. 2014.

Kritzinger, K., 2011, “"Mission as...” must we choose?', Missionalia, Vol. 39, No 1-2 April/August 2011:32-59.

Manchala, D., Rajkumar, P. and Prabhakar D.J., 2013, 'When margins inform and re-form mission' in Wild-Wood, E. and Rajkumar, P. (eds.), Foundations for mission. Oxford: Regnum: 30-42.

McCoy, M., 2013, 'Restoring mission to the heart of theological education' in Phiri, I.A. and Werner, D. (eds.), 2013, Handbook of theological education in Africa. Dorpspruit: Cluster: 523-529. 
Moynagh, M. and Harrold, P., 2012, Church for every context. An introduction to theology and practice. London: SCM Press.

Netland, H.A., 2006, 'Introduction' in Ott, C. and Netland, H.A., (eds.), Globalizing theology. Belief and practice in an era of World Christianity. Grand Rapids: Baker: 14-36.

Niemandt, N., 2007, Nuwe drome vir nuwe werklikhede. Geloofsgemeenskappe in pas met 'n postmoderne wêreld. Wellington: LuxVerbi.BM

Niemandt, C.J.P., 2011, “"Blogging” David Bosch and Transforming Mission', Missionalia Vol. 39 No. 1-2 April/August 2011, pp.60-81.

Niemandt, C.J.P., 2012, Missional leadership - entering the trialogue. Inaugural address of Professor CJP (Nelus) Niemandt as head of the Department Science of Religion and Missiology 9 May 2012. See http://repository.up.ac.za/handle/2263/18785 Accessed 7 August 2013.

Niemandt, N., 2013, Nuwe leiers vir nuwe werklikhede. Vereeniging: CUM.

Osmer, R.R., 2008, Practical Theology. An introduction. Grand Rapids: Eerdmans.

Ott, C., 2006, 'Conclusion: Globalizing Theology' in Ott, C. and Netland, H.A., (eds.), Globalizing theology. Belief and practice in an era of World Christianity. Grand Rapids: Baker: 309-336.

Pears, A., 2010, Doing contextual theology, New York: Routledge. [Kindle]

Ross, C., 2008, 'Introduction: Taonga', in Walls, A. and Ross, C. (eds.) Mission in the 21st Century. Exploring the five marks of global mission. London: Darton, Longman And Todd: xiii-xvi.

Roxburgh, A.J., 2011, Missional. Joining God in the neighbourhood. Grand Rapids: Baker. [Kindle].

Shenk, W.R., 2006, Foreword in Ott, C. and Netland, H.A., (eds.), Globalizing theology. Belief and practice in an era of World Christianity. Grand Rapids: Baker: 9-11.

Stone, R.M., 2013, Eat with joy: redeeming God's gift of food. Downers Grove: InterVarsity Press.

So, D.W.K., 2013, 'Christology and Trinity in mission', in Wild-Wood, E. and Rajkumar, P. (eds.), Foundations for mission. Oxford: Regnum:123-137. 
Sweet, L., 2010, Nudge. Awakening each other to the God who's already there. Colorado Springs: David Cook.

Tennent, T., 2010. Invitation to World Missions: A Trinitarian Missiology for the Twenty-first Century. Grand Rapids: Kregel [Kindle].

Ukpong, J., 2013, 'Inculturation theology in Africa: Historical and hermeneutical developments' in Phiri, IA and Werner, D (eds.), 2013, Handbook of theological education in Africa. Dorpspruit: Cluster: 530-542.

Van Engen, C.E., 2006, 'The glocal church. Locality and Catholicity in a globalizing world' in Ott, C. and Netland, H.A., (eds.), Globalizing theology. Belief and practice in an era of World Christianity. Grand Rapids: Baker.

Volf, M., 2006. 'Being as God is' in Volf, M and Welker, M (eds.), God's life in Trinity. Minneapolis: Fortress Press: 3-12.

Volf, M. 2009. Themes in Faith and Globalization, The faith and globalization initiative, Yale centre for Faith and Culture, audio lectures. See http://www.coursehero.org/lecture/themes-faith-andglobalization. Accessed on 9 Dec. 2014.

Walls, A.F., 1996, The Missionary Movement in Christian History: Studies in the Transmission of Faith. Maryknoll, NY: Orbis.

Walls, A.F., 2009, Christianity across twenty centuries, in Johnson, T.M. and Ross, K.R. (eds.) Atlas of global Christianity 1910-2010. Edinburg: Edinburgh University Press: 48-49.

West, G., 2013. 'The school of Religion, Philosophy, and Classics: doing contextual theology in Africa in the University of KwaZulu-Natal' in Phiri, IA and Werner, D (eds.), 2013, Handbook of theological education in Africa. Dorpspruit: Cluster: 919-926.

Wirzba, N., 2011, Food and faith. A theology of eating. New York: Cambridge University Press.

World Council of Churches, 2013, Resource Book, World Council of Churches 10th Assembly Busan, 2013. Geneva: WCC Publications.

Wright, N.T., 2008, Surprised by hope, New York: HarperOne. 